
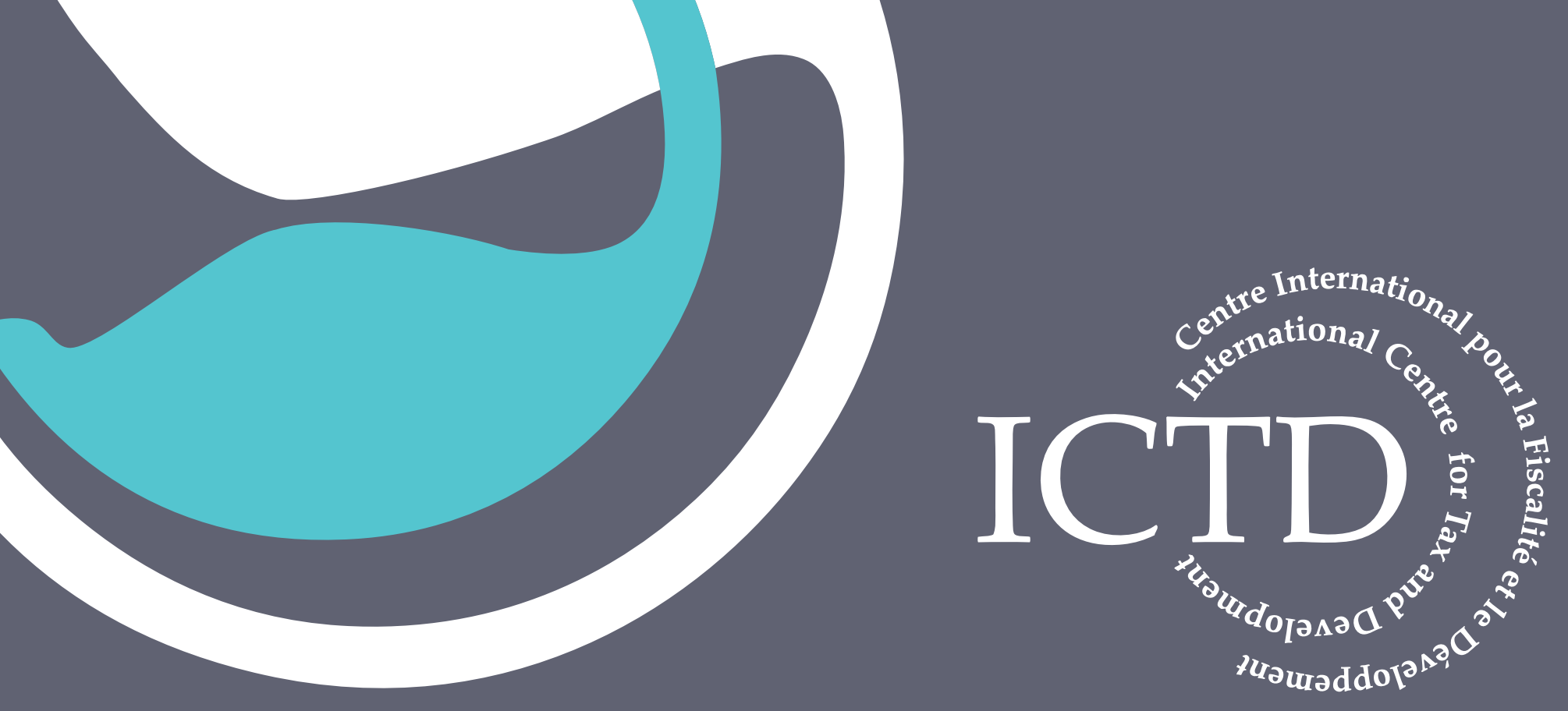

Working Paper 43

\title{
Business people's views of paying taxes in Ethiopia
}

Wollela Abehodie Yesegat and Odd-Helge Fjeldstad January 2016 
ICTD Working Paper 43

\section{Business people's views of paying taxes in Ethiopia}

Wollela Abehodie Yesegat and Odd-Helge Fjeldstad

January 2016 
Business people's views of paying taxes in Ethiopia Wollela Abehodie Yesegat and Odd-Helge Fjeldstad ICTD Working Paper 43

First published by the Institute of Development Studies in January 2016

(C) Institute of Development Studies 2016

ISBN: 978-1-78118-282-6

A catalogue record for this publication is available from the British Library.

All rights reserved. Reproduction, copy, transmission, or translation of any part of this publication may

be made only under the following conditions:

- with the prior permission of the publisher; or

- with a licence from the Copyright Licensing Agency Ltd., 90 Tottenham Court Road, London W1P 9HE, UK, or from another national licensing agency; or

- under the terms set out below.

This publication is copyright, but may be reproduced by any method without fee for teaching or nonprofit purposes, but not for resale. Formal permission is required for all such uses, but normally will be granted immediately. For copying in any other circumstances, or for reuse in other publications, or for translation or adaptation, prior written permission must be obtained from the publisher and a fee may be payable.

Available from:

The International Centre for Tax and Development

at the Institute of Development Studies

Brighton BN1 9RE, UK

Tel: +44 (0) 1273606261 Fax: +44 (0) 1273621202

E-mail: info@ictd.ac.uk

Web: www.ictd/en/publications

IDS is a charitable company limited by guarantee and registered in England (No. 877338) 


\title{
Business people's views of paying taxes in Ethiopia
}

\author{
Wollela Abehodie Yesegat and Odd-Helge Fjeldstad
}

\section{Summary}

This study examines factors that determine business people's attitudes towards paying taxes in Ethiopia. Based on data obtained from a survey of business taxpayers in Addis Ababa, the study finds a statistically significant relation between tax-compliance attitude and factors such as the perception of probability of audit, corruption, satisfaction with the tax administration, peer influence, gender and education. The study emphasises the need for better understanding of why taxpayers are dissatisfied with the tax administration, including perceptions of corrupt practices.

Keywords: tax; compliance; perceptions; attitudes; rates; audit; penalty.

Wollela Abehodie Yesegat is Assistant Professor at the College of Business and Economics, Addis Ababa University, Ethiopia.

Odd-Helge Fjeldstad is Senior Researcher at the Chr. Michelsen Institute, Norway; Research Director at the International Centre for Tax and Development; and Extraordinary Professor at the African Tax Institute, University of Pretoria, South Africa. 


\section{Contents}

Summary 3

Acknowledgements $\quad 5$

$\begin{array}{ll}\text { Introduction } & 6\end{array}$

$1 \quad$ Tax compliance: theoretical perspectives and empirical evidence $\quad 7$

2 Research objective and hypotheses 9

3 Data sources and variables $\quad 9$

3.1 Dependent variable: tax compliance attitude 9

$\begin{array}{ll}3.2 & \text { Independent variables } \\ & 10\end{array}$

4 Results $\quad 11$

$\begin{array}{lll}4.1 & \text { Descriptive statistics } & 11\end{array}$

4.2 Model specification and regression analysis 13

4.2.1 Tax compliance attitude: 'One should honestly declare
all income on one's tax return'

4.2.2 Tax compliance attitude: 'How frequently do you think
taxpayers (implicitly including themselves) evade taxes?'

$5 \quad$ Discussion and conclusions $\quad 16$

$\begin{array}{ll}\text { References } & 19\end{array}$

Tables

Table $1 \quad$ Data description 12

$\begin{array}{lll}\text { Table } 2 & \text { Wald test for ordered probit regression } & 14\end{array}$

$\begin{array}{lll}\text { Table } 3 & \text { Ordered probit regressions with marginal effects } & 15\end{array}$ 


\section{Acknowledgements}

We are grateful to Dr Alemu Mekonnen Getnet for his help in some of the quantitative analysis of the study. Useful comments on earlier drafts were received from participants at ICTD's annual research conference, Arusha, Tanzania, 7-9 December 2014, Ingrid Hoem Sjursen and two anonymous reviewers. Points of view and errors rest entirely with the authors. Financial support from the International Centre for Tax and Development is highly appreciated. 


\section{Introduction}

Recently, the Ethiopian economy has been performing well. World Bank (n.d. a) notes that the Ethiopian economy has experienced a strong, broad-based growth over the past decade, averaging 10.8 per cent per year 2003/04 - 2012/13, compared to the regional average of 5.3 per cent. Sustaining this growth requires, among other things, strong domestic revenue mobilisation. Fiscal performance, particularly tax collection in absolute terms, is increasing: tax revenue covers over 70 per cent of total government expenditure, and the tax-expenditure gap is declining. However, in terms of the tax-to-GDP ratio, revenue performance is still at a low level - approximately 13 per cent; this is lower than the average for low-income countries. ${ }^{1}$ This low revenue performance is likely to create pressure on the government to realise its revenue collection target, leading to coercive tax enforcement practices and an unfair burden on complying taxpayers. ${ }^{2}$ The burden of tax compliance expressed in terms of average tax compliance costs as a share of turnover was estimated to be 5.4 per cent (IFC unpublished). Further, IFC (unpublished) notes regressivity in tax compliance costs, in that smaller businesses bear a disproportionately heavy tax compliance burden. Such pressure is likely to lead to taxpayers' resentment. This may, in turn, have an adverse impact on taxpayers' willingness to comply voluntarily, which is instrumental in enhancing the efficiency and equity of the tax system, and domestic revenue mobilisation.

Taxpayers' resentment and noncompliance may be due to taxpayers' perceptions and attitudes on paying taxes. Several theories and models have been developed, attempting to explain tax compliance behaviour. McKerchar (2001) identifies three broad models explaining tax compliance behaviour - economic deterrence, social psychology, and fiscal psychology models - with the latter being a mix of the first two. ${ }^{3}$ Fjeldstad et al. (2012) suggest that models and theories of taxpayer behaviour tend to reflect one of five schools of thought - economic deterrence, fiscal exchange, social influences, comparative treatment and political legitimacy; these are interconnected, and some represent an evolution of the others. These models emphasise the importance of attitudes and perceptions on various aspects of a tax system (Cullis and Lewis 1997; McKerchar 2002; Alm et al. 1999).

Rooted in these theoretical frameworks, many empirical studies have assessed taxpayers' perceptions and attitudes towards tax systems. However, to the knowledge of authors, there appears to be no study that examines taxpayers' views of the tax system in Ethiopia.

Understanding taxpayers' behaviour and taking corrective measures is important in order to enhance domestic revenue mobilisation and sustain Ethiopia's recent growth. Hence, the purpose of this study is to examine the association between tax compliance attitude and perceptions on aspects of the Ethiopian tax system. The results of the study are expected to inform reform of both tax policy and administration procedures in the country.

The remaining part of the paper is organised as follows. Section 1 presents the theoretical framework for the study. Section 2 presents the research objective and hypotheses, followed by

Further, it remains low in the context of the government's plan of increasing it to 15.3 per cent by the end of its Growth and Transformation Plan (GTP), 2014/15.

Revenue performance is an important indicator for the efficiency of a tax administration and the pressure the administration faces to increase its collection efforts. World Bank (n.d. b) notes that a low percentage of tax revenue-to-GDP generally means that the tax administration is facing pressure to increase its collection performance considerably.

3

There has been considerable cross-fertilisation and concurrent evolution both within and across these approaches (McKerchar 2001). 
sources of data and variables in Section 3. Section 4 presents the results, and Section 5 concludes.

\section{Tax compliance: theoretical perspectives and empirical evidence}

Tax compliance is a complex behavioural issue. As noted earlier, models and theories of taxpayer behaviour tend to reflect different economic, social and psychological approaches to explain taxpaying behaviour.

This paper does not examine these models in detail. ${ }^{4}$ Instead, the following paragraphs briefly present the key compliance models and theories that provide the foundation for the research hypotheses presented in Section 2.

Allingham and Sandmo (1972) developed the economic deterrence model, following the economics of crime approach pioneered by Becker (1968). The model analyses the individual taxpayer's decision on whether, and to what extent, to evade taxes through intentional underreporting of taxable income. The model predicts whether a taxpayer will evade tax, depending on the benefit of evasion relative to the expected cost of being detected and punished. According to this model, taxpayers evade taxes if their decision maximises their expected profit (or utility). Allingham and Sandmo (1972) conclude that an increase in the penalty rate would increase the fraction of actual income declared, and an increase in the probability of being detected would also lead to a larger income being declared. The model is very simplistic (as acknowledged by Allingham and Sandmo), in that it ignores other factors that might affect the decision of whether to comply or not.

Tax compliance appears to be affected by other factors, rather than solely by the expected benefits of compliance. Apart from the economic aspects of compliance, the literature emphasises the significance of assessing compliance in the context of non-economic factors. ${ }^{5}$ This leads to the social and psychological models. Social and psychological insights have contributed to better understanding of the observed level of tax compliance (e.g. Alm et al. (1999); Cullis and Lewis (1997); McKerchar (2002)). These models, unlike the economic deterrence model, look at tax compliance behaviour in an environment of social interactions and conventions. In these models tax compliance is influenced by a range of factors, including attitudes, perceptions, beliefs, personality traits and interactions between the actors (taxpayers, tax administrators/the state, tax advisors, and others).

The social psychology model, unlike the economic deterrence model, pertains to the relationship between tax compliance and social interactions and conventions. An aspect of this theory says that perceptions and attitudes towards a tax system and compliance behaviour may be affected by the behaviour of an individual's peer groups. The compliance behaviour of peer groups like friends, neighbours and relatives is expected to impact on the perceptions and compliance decisions of others. More specifically, noncompliant decisions by peer groups may reduce the level of tax compliance by others.

For a detailed analysis of the different compliance models and theories, see McKerchar (2002) and Fjeldstad et al. (2012). e.g. Cullis and Lewis (1997), Andreoni et al. (1998), Torgler (2002) and McKerchar (2002). 
The other aspect of social psychology theory is related to social sanctions. Social sanctions and attitudes towards them may affect the level of tax compliance. The severity of social sanctions against noncompliant taxpayers and attitudes towards them may increase willingness to comply. Regarding the above points, Fjeldstad et al. (2012) argue that compliance behaviour and attitudes towards the tax system may be affected by the behaviour of an individual's reference groups. If a taxpayer knows many people in groups important to him/her who evade taxes, his/her commitment to comply will be weaker. On the other hand, social relationships may also help deter individuals from engaging in evasion for fear of the social sanctions imposed once discovered and publicly revealed.

Fiscal exchange theory (as an aspect of fiscal psychology), says that effective provision of public goods and services (government expenditure) may increase the level of compliance by taxpayers. Alm et al. (1992) suggest that individuals pay taxes voluntarily because they value the goods provided by government, and they recognise that their payment may be necessary to get others to contribute. A government may increase compliance by providing goods that citizens need more, by providing public goods and services in a more efficient manner, or by more effectively emphasising that taxes are necessary for the receipt of government services (Alm et al. 1992). Fjeldstad et al. (2012) also note that the existence of positive benefits may increase the probability that taxpayers will comply voluntarily, without direct coercion. In general, it can be argued that taxpayers' satisfaction or dissatisfaction with the government's provision of goods and services is expected to have an impact on tax compliance.

The literature further identifies comparative treatment of taxpayers as a factor that is expected to have a bearing on tax compliance behaviour. The comparative treatment perspective implies that taxpayers may consider how the state, and the tax administration in particular, treats them relative to their fellow taxpayers. If taxpayers perceive that the tax administration treats certain groups favourably, this may affect their relationship with the tax administration, the state at large, and the group receiving favours, and hence may impact on their willingness to comply. D'Arcy (2011) argues that citizens think about how the state treats them relative to their fellow citizens; this judgment will affect not only their judgment of the state, but also how they view their peers.

In relation to the fiscal exchange and comparative treatment theories, there is a notion that a legitimate government may encourage tax compliance. A government's legitimacy rests on its impartiality, its proven ability to treat citizens equally in its dealings with them, and to adjudicate impartially in disputes between them. Upon this rests not only the citizen's trust in government, but also their trust in each other (D'Arcy 2011). Fjeldstad et al. (2012) also argue that the more accountable the government is with taxpayers' funds, the more legitimate its actions become.

Compliance is also affected by sociological and demographic factors. For instance, there may be differences in perception about taxation between age groups, urban-rural location, gender, education levels, occupation, ethnicity, religion, and so on (Fjeldstad et al. 2012).

In the context of the theories discussed so far, there are a number of empirical studies on tax compliance in developing countries. These studies include the works of the Nepal Ministry of Finance and German Technical Cooperation (GTZ) (2010) - Nepal; Wadhawan and Gray (1998) - Africa; Saad (2011) - Malaysia and New Zealand; Loo et al. (2008, 2009) - Malaysia; Fjeldstad and Semboja (2001) - Tanzania; Marti et al. (2010) - Kenya; Coolidge and llic (2009) - South Africa; D'Arcy (2011) - Africa; Yesegat (2009) - Ethiopia; and Ali et al. (2014) - Kenya, Tanzania, Uganda and South Africa. Other studies, including Sapiei et al. (2014) and Hanlon et 
al. (2005), also investigate the impact of business characteristics such as business size and business sector on tax compliance behaviour.

These studies examine perceptions and attitudes, and their impact on taxpayers' compliance. Most of these studies are based on surveys of taxpayers and other stakeholders. They show the importance of building positive perceptions and attitudes towards the various aspects of taxes. Although there have been studies on perceptions and attitudes towards taxes in some developing countries, there appear to be no studies that examine the view of taxpayers on paying taxes in Ethiopia. We do not know how Ethiopian taxpayers perceive the tax system and their tax compliance behaviour.

\section{Research objective and hypotheses}

The broad objective of the study is to assess business people's perceptions of the tax system and compliance attitudes in Ethiopia. The following research hypotheses (HP) were developed based on theoretical models and studies conducted in other countries:

H1. Attitudes to paying taxes are influenced by the perception of government services; perception of tax rates, penalty and audit; perception of others/peer compliance; perception of government treatment of taxpayers (perception of discrimination by the tax administration); trust in the administration; satisfaction with the tax administrative procedures and practices; and perception of corruption in the tax administration.

H2. Attitudes to paying taxes are influenced by age, gender, education level achieved, business size and sector.

\section{Data sources and variables}

This study is based on a survey of 500 business taxpayers residing in Addis Ababa, stratified by sector and size, and selected randomly. The survey covered all business size groups ${ }^{6}$ and sectors. The survey used a five-point Likert Scale, ranging from 1 (strongly agree) to 5 (strongly disagree). The survey instrument was informed by results from in-depth interviews held with taxpayers and tax advisors. The survey was conducted from January to September 2014. Subsequent paragraphs discuss definition of the variables.

\subsection{Dependent variable: tax compliance attitude}

We use two alternate measures to capture tax compliance attitude. First, we use responses to a more direct question: 'One should honestly declare all income on one's tax return'. The responses range from 'strongly agree' $=1$ to 'strongly disagree' $=5$. Secondly, following a similar approach to that adopted by Torgler and Schneider (2006) and Ali et al. (2014), we measure tax compliance attitude in terms of responses to an indirect question: 'How frequently do you think taxpayers (implicitly including themselves) evade taxes?'. The responses are categorised as 'very frequently' $=1$, 'frequently' $=2$, 'not so often' $=3$, 'sometimes' $=4$ and 'never' $=5$. 


\subsection{Independent variables}

\section{Perception of tax rates as high, tax audit as low, and penalty as likely}

According to the different tax compliance models presented above, the taxpayers' compliance decision is affected by actual and perceived tax rates, probability of audit and penalty. The survey used a five-point Likert Scale: 'strongly agree' $=1$, 'agree' $=2$, 'neutral' $=3$, 'disagree' $=$ 4 and 'strongly disagree' $=5$. For the variable tax rate, we use a composite factor from the responses to the following statement: 'In general tax rates in Ethiopia are very high, and the combined dividend and corporate tax rate is high'.

With respect to perception of penalty, the study uses responses to the statement: 'Failure to pay taxes to the tax authority (Ethiopian Revenues and Customs Authority (ERCA)) leads to strict punishment'. Similarly, for the audit perception variable we use responses to the statement: 'The probability of audit is low'.

\section{Perception of government services as good}

Respondents were asked questions about their view of government services. Some of the statements are sensitive, and their responses should be viewed with caution. For example, responses to the statement: 'Even though the government is providing low services we have to pay our fair share of taxes' may not be honest. Similar to other variables, the study uses a composite factor of the responses to the following statements: 'The government is using the tax money in a reasonable way', and 'We receive good services for the tax money we pay'.

\section{Perception of discrimination by the tax administration as high (comparative treatment)}

In order to assess the correlation of perception of discrimination by the tax authority and tax compliance attitude, we use a composite factor from the responses to the following statements: 'The feeling that they are unfairly treated by the tax administration compared to other taxpayers', 'Discrimination by the tax administration (based on some network) forces honest taxpayers to evade taxes', and 'The tax administration does not control some taxpayers who fail to comply, indicating the existence of discrimination by the tax administration'.

\section{Political legitimacy assessed in terms of three variables (perception of corruption as high, perception of trust in tax administration as high, and perception of tax administration as satisfactory}

Perception of corruption is measured using a composite factor from responses to statements: 'Tax officials often show corrupt behaviour', and 'Tax officers often ask for unofficial payment and fees'. Perceived trust is captured with responses to the statement: 'You trust that the tax administration's decisions are genuine and honest'. Furthermore, as a measure of satisfaction with the tax administration, we use a composite factor based on responses to the following statements: 'Responses of tax officials to your query/problems are helpful and reasonable', 'Tax officers show friendly behaviour to you', 'Time taken to get your job done/requests addressed is fairly good', 'The information taxpayers get from the tax office is consistent and timely', 'The tax authority provides good quality of taxpayers services', 'The general attitude of tax officials towards solving taxpayers' problems is good', and 'The tax authority treats you as acting honestly in meeting your tax obligations'. 


\section{Perception of others' compliance behaviour (peer compliance) as low}

The study assessed the impact of perception of peer compliance on compliance attitude using a composite factor based on responses to the following statements: 'Difficult to compete with those who got their products/goods without paying the appropriate taxes and duties', 'The knowledge that their neighbours are evading taxes forces honest taxpayers to evade taxes', and 'In the current tax system, it is unfair that we pay the required tax but others who earn the same income are not paying'.

In addition, the study considers the following variables:

Age (less than 35 years of age as a reference)

- Dummy variable that takes the value of 1 if the respondent is 35 years of age and above, 0 otherwise;

Gender (male as a reference)

- Dummy variable that equals 1 if the gender is female and 0 otherwise;

Business size (business annual turnover less than ETB 100,000 as a reference)

- Dummy variable that equals 1 if the annual turnover is ETB 500,000 and above, and 0 otherwise;

- Dummy variable that equals 1 if the annual turnover is from ETB 100,000 to ETB 500,000 and 0 otherwise

Highest level of education achieved (no formal education as a reference)

- Dummy variable that equals 1 if the highest level of education achieved is University Degree or above and 0 otherwise;

- Dummy variable that equals 1 if the highest level of education achieved is Diploma and Certificate and 0 otherwise;

- Dummy variable that equals 1 if the highest level of education achieved is high school education and 0 otherwise;

Business sector (others including agriculture as a reference)

- Dummy variable that equals 1 if the sector is manufacturing, construction and real estate and 0 otherwise;

- Dummy variable that equals 1 if the sector is trade (both wholesale and retail) and 0 otherwise;

- Dummy variable that equals 1 if the sector is professional services and 0 otherwise;

\section{Results}

We present the descriptive statistics first, followed by a specification of the model and regression results.

\subsection{Descriptive statistics}

We use two alternate proxies to measure compliance attitude, as discussed earlier. The first measure is based on responses to the statement: 'One should honestly declare all income on one's tax return'. Responses to this statement range from 'strongly agree' $=1$ to 'strongly disagree' $=5$. Table 1 shows a mean value of 1.57 for compliance attitude (using this first measure), suggesting that perception of noncompliance is low. Similarly, under the second measure of tax compliance attitude (using the question on the extent of tax evasion), responses 
range from 'very frequently' $=1$, to 'never' $=5$. Using this second measure, the mean value of tax compliance attitude was found to be more than 3 , also suggesting a low level of tax noncompliance attitudes (Table 1).

Table 1 Data description*

\begin{tabular}{|c|c|c|c|c|c|}
\hline Variables & Obs & Mean & Std & Min & Max \\
\hline $\begin{array}{l}\text { Compliance attitude (based on a direct question) (strongly agree (1) to } \\
\text { strongly disagree (5)) }\end{array}$ & 497 & 1.57 & 0.64 & 1 & 5 \\
\hline $\begin{array}{l}\text { Compliance attitude (based on frequency of evasion) (very frequently (1) } \\
\text { to never (5)) }\end{array}$ & 329 & 3.24 & 1.14 & 1 & 5 \\
\hline $\begin{array}{l}\text { Perception of trust in tax administration as high (strongly agree (1) to } \\
\text { strongly disagree (5)) }\end{array}$ & 336 & 3.43 & 1.06 & 1 & 5 \\
\hline Perception of penalty as likely (strongly agree (1) to strongly disagree (5)) & 331 & 1.90 & 0.66 & 1 & 4 \\
\hline Perception of audit as low (strongly agree (1) to strongly disagree (5)) & 336 & 2.95 & 1.10 & 1 & 5 \\
\hline Dummy for education Uni and above (no formal education as a reference) & 337 & 0.44 & 0.50 & 0 & 1 \\
\hline Dummy for education Dip. and Cert. (no formal education as a reference) & 337 & 0.22 & 0.42 & 0 & 1 \\
\hline $\begin{array}{l}\text { Dummy for manufacturing sector (others including agricultural sector as a } \\
\text { reference) }\end{array}$ & 337 & 0.32 & 0.47 & 0 & 1 \\
\hline $\begin{array}{l}\text { Perception of others' compliance as low (strongly agree (1) to strongly } \\
\text { disagree (5)) }\end{array}$ & 332 & 2.15 & 0.72 & 1 & $4.33^{\star \star}$ \\
\hline $\begin{array}{l}\text { Perception of discrimination by tax admin as high (strongly agree (1) to } \\
\text { strongly disagree (5)) }\end{array}$ & 332 & 2.55 & 0.81 & 1 & $4.67^{\star \star}$ \\
\hline $\begin{array}{l}\text { Dummy for turnover ETB 500,000 and above (turnover up to ETB 100,000 } \\
\text { as a reference) }\end{array}$ & 337 & 0.51 & 0.50 & 0 & 1 \\
\hline $\begin{array}{l}\text { Dummy for turnover ETB } 100,000 \text { to } 500,000 \text { (turnover up to ETB } 100,000 \\
\text { as a reference) }\end{array}$ & 337 & 0.28 & 0.46 & 0 & 1 \\
\hline Age group ( 1 if age is 35 years and above, 0 otherwise) & 335 & 0.55 & 0.50 & 0 & 1 \\
\hline $\begin{array}{l}\text { Dummy professional services (others including agricultural sector as a } \\
\text { reference) ( } 1 \text { if professional services, } 0 \text { otherwise) }\end{array}$ & 335 & 0.19 & 0.39 & 0 & 1 \\
\hline $\begin{array}{l}\text { Dummy trade (others including agricultural sector as a reference) (1 if } \\
\text { trade, } 0 \text { otherwise) }\end{array}$ & 335 & 0.48 & 0.50 & 0 & 1 \\
\hline $\begin{array}{l}\text { Dummy manufacturing sector (others including agricultural sector as a } \\
\text { reference) ( } 1 \text { if manufacturing, } 0 \text { otherwise) }\end{array}$ & 335 & 0.24 & 0.43 & 0 & 1 \\
\hline $\begin{array}{l}\text { Perception of government services as good (strongly agree (1) to strongly } \\
\text { disagree (5)) }\end{array}$ & 335 & 2.78 & 0.91 & 1 & 5 \\
\hline Perception of tax rates as high (strongly agree (1) to strongly disagree (5)) & 331 & 1.96 & 0.77 & 1 & $4.5^{\star *}$ \\
\hline $\begin{array}{l}\text { Perception of tax administration as satisfactory (strongly agree (1) to } \\
\text { strongly disagree (5)) }\end{array}$ & 332 & 3.28 & 0.78 & $1.25^{\star \star}$ & 5 \\
\hline $\begin{array}{l}\text { Perception of corruption as high (strongly agree (1) to strongly disagree } \\
\text { (5)) }\end{array}$ & 336 & 3.38 & 0.79 & 1 & 5 \\
\hline Gender of respondent ( 1 if gender is female, 0 otherwise) & 335 & 0.22 & 0.42 & 0 & 1 \\
\hline
\end{tabular}

Note:

*The variables listed in the table, except the first two, are all explanatory variables used in the regression analysis. We present the descriptive statistics for those businesses that were included in the regression analysis for compliance attitude using the indirect question.

** These are composite factors.

Source: survey results and own computations.

The description of variables in this paragraph is based on responses to statements in the survey that range from 'strongly agree' $=1$ to 'strongly disagree' $=5$. The results show that the respondents generally have a low level of trust in decisions of tax administrators $(\bar{x}=3.43, \sigma=$ 1.06). The respondents generally agree that failure to pay taxes due would lead to heavy penalty $(\bar{x}=1.9, \sigma=0.66)$, and do not agree that the probability of detection (audit) is low $(\bar{x}=$ 2.95, $\sigma=1.10)$. The respondents also generally perceive tax rates as high $(\bar{x}=2.19, \sigma=0.77)$. In respect of perception of others' compliance, respondents appear generally to agree to statements including 'In the current system we pay taxes but others do not' $(\bar{x}=2.15, \sigma=0.72)$. Further, respondents tend not to agree that tax officers show corrupt behaviour and tax officers ask for unofficial payments and benefits $(\bar{x}=3.38, \sigma=0.79)$. In terms of their perception of 
satisfaction with the tax administration procedures and practices, the respondents generally do not agree with the statements: 'Responses of tax officials to your query/problems are helpful and reasonable', 'Tax officers show friendly behaviour to you', 'Time taken to get your job done/requests addressed is fairly good', 'The information taxpayers get from the tax office is consistent and timely', 'The tax authority provides good quality of taxpayers services', 'The general attitude of tax officials towards solving taxpayers' problems is good', and 'The tax authority treats you as acting honestly in meeting your tax obligations' $(\bar{x}($ composite $)=3.28, \sigma=$ 0.78).

Of the respondents, 78 per cent were male and 55 per cent were 35 years old and above. In terms of education, the data shows that 44 per cent of respondents had a University Degree and above level of educational achievement, while 22 per cent had Diploma and Certificate level achievement. About 50 per cent of the surveyed businesses had an annual turnover of ETB 500,000 and above.

About 40 per cent of the respondents were owners or managers -21 per cent were owners and 18 per cent managers. The survey data shows that about 80 per cent of the respondents visited the tax office less than two months before the survey was conducted, while the rest visited tax offices more than two months before the survey, indicating that when the survey was conducted most respondents had very recent experience with the tax system.

\subsection{Model specification and regression analysis}

We use responses to two alternate survey questions to capture tax compliance attitude. The first question (more direct) is: 'One should honestly declare all income on one's tax return'; the responses are categorised as 'strongly agree', 'agree', 'neutral', 'disagree' and 'strongly disagree'. Those who respond 'agree' or 'strongly agree' are assumed to have a compliant attitude; others are considered as having a noncompliant attitude. Similarly, with the indirect survey question about tax noncompliance, responses are categorised as 'very frequently', 'frequently', 'not so often', 'sometimes' and 'never'. We use 'never' as a cut-off point, and treat it as a measure of compliant attitude; responses indicating the existence of evasion in different levels of frequency are considered as measures of a noncompliant attitude. Similar to Torgler and Schneider (2006), we drop 'do not know' from the analysis. Considering the ordinal nature of the dependent variable, we use an ordered probit model. ${ }^{7}$

The general estimation equation:

$$
\begin{aligned}
Y=C+ & \beta_{1} X_{1}+\beta_{2} X_{2} \ldots+\beta_{k} X_{k}+u \\
& \text { Where } \\
Y & =\text { dependent variable; } \\
C & =\text { constant; } \\
X_{j} & =\text { independent variable where } j \text { runs from } 1 \text { to } k ; \\
\beta_{j} & =\text { coefficient of the independent variable } j ; \text { and } \\
u & =\text { classical random error term. }
\end{aligned}
$$

In showing the appropriateness of an ordered probit model for this type of dataset, Greene (2002) states that although the outcome is discrete, the multinomial logit or probit model would fail to account for the ordinal nature of the dependent variable. Ordered probit and logit models have come into fairly wide use as a framework for analysing such responses (Zavoina and McElvey 1975, cited in Greene 2002). 
The following discussion presents the results under both ways of measuring tax compliance attitude.

\subsubsection{Tax compliance attitude: 'One should honestly declare all income on one's tax return'}

We analyse compliance attitude using responses to the question: 'One should honestly declare all income on one's tax return'. The responses are categorised into 'strongly agree' and 'agree', 'neutral', 'disagree' and 'strongly disagree'. About 98 per cent of the respondents agreed (representing compliant attitude), while the rest were neutral or disagreed.

This result should be interpreted with caution - nearly 100 per cent of the respondents agree with the statement, implying that the dependent variable is almost a constant. In addition, responses may not be honest due to the nature of the question. Tax noncompliance is illegal and a concealed activity. Gathering data on the compliance behaviour of taxpayers through field data collection methods such as interviews and mail surveys suffers from the unwillingness of respondents to reply honestly to questions about their own compliance. Consequently, field data obtained through direct questioning of taxpayers about their compliance behaviour is considered to be inaccurate and unreliable by some scholars. Others, such as Reinikka and Svensson (2006), however, argue that, using appropriate survey methods and interview techniques, the problem of exaggerated responses can be reduced and that collection of empirical data on such sensitive issues as corruption is possible. To deal with the caveat mentioned above, we capture tax compliance attitude with responses to an indirect question, as discussed in the following section.

\subsubsection{Tax compliance attitude: 'How frequently do you think taxpayers (implicitly including themselves) evade taxes?'}

In this section we measure compliance attitude by responses to the question: 'How frequently do you think taxpayers (implicitly including themselves) evade taxes?' The responses are 'very frequently' $=1$, 'frequently' $=2$, 'not so often' $=3$, 'sometimes' $=4$, and 'never' $=5$. We report ordered probit regression results below.

In the ordered probit analysis we categorise responses into five categories ('very frequently' $=1$, 'frequently' $=2$, 'not so often' $=3$, 'sometimes' $=4$ and 'never' $=5$ ).

We run a robust ordered probit regression model. The results show that the overall regression was statistically significant $(p-$ Value $=0.0000)($ Table 2$)$.

Table 2 Wald test for ordered probit regression

\begin{tabular}{ll}
\hline Number of Obs & 311 \\
\hline Wald Ch2 (16) & 93.4 \\
\hline Prob > Chi2 & 0.0000 \\
\hline Pseudo R2 & 0.0991 \\
\hline
\end{tabular}

Source: survey results and own computations.

Since the equation in an ordered probit model is nonlinear, only the signs of the coefficients can be directly interpreted and not their size. To assess the quantitative effects of the independent variables, marginal effects are calculated. Table 3 presents the marginal effects of ordered probit regression for the five categories (very frequently, frequently, not so often, sometimes and 
never). Several factors are found to have a statistically significant correlation with compliance attitude.

Table 3 Ordered probit regressions with marginal effects

\begin{tabular}{|c|c|c|c|c|c|}
\hline & $\begin{array}{l}\text { Very } \\
\text { frequently }\end{array}$ & Frequently & $\begin{array}{l}\text { Not so } \\
\text { often }\end{array}$ & Sometimes & Never \\
\hline \multirow[t]{2}{*}{ Perception of trust in tax administration } & -0.011 & -0.014 & -0.004 & 0.017 & 0.012 \\
\hline & $(0.010)$ & $(0.013)$ & $(0.004)$ & $(0.015)$ & $(0.011)$ \\
\hline \multirow[t]{2}{*}{ Perception of penalty as likely } & $0.028^{\star *}$ & $0.036^{\star *}$ & $0.011^{*}$ & $-0.044^{* *}$ & $-0.031^{\star *}$ \\
\hline & $(0.014)$ & $(0.017)$ & $(0.006)$ & $(0.021)$ & $(0.015)$ \\
\hline \multirow[t]{2}{*}{ Perception of audit probability as low } & $-0.028^{\star \star \star}$ & $-0.036^{\star \star \star}$ & $-0.011^{\star \star \star}$ & $0.043^{\star \star \star}$ & $0.031^{\star \star \star}$ \\
\hline & $(0.008)$ & $(0.010)$ & $(0.004)$ & $(0.011)$ & $(0.009)$ \\
\hline \multirow{2}{*}{$\begin{array}{l}\text { Dummy for education Uni and above (no } \\
\text { formal education as a reference) }\end{array}$} & $0.188^{\star \star \star}$ & $0.240^{\star \star \star}$ & $0.073^{\star *}$ & $-0.292^{* * *}$ & $-0.209^{\star \star *}$ \\
\hline & $(0.073)$ & $(0.089)$ & $(0.029)$ & $(0.108)$ & $(0.079)$ \\
\hline \multirow{2}{*}{$\begin{array}{l}\text { Dummy for education Dip. and Cert. (no } \\
\text { formal education as a reference) }\end{array}$} & $0.166^{\star \star}$ & $0.212^{\star \star}$ & $0.065^{\star \star}$ & $-0.259^{\star \star}$ & $-0.184^{\star \star}$ \\
\hline & $(0.073)$ & $(0.089)$ & $(0.028)$ & $(0.107)$ & $(0.078)$ \\
\hline \multirow{2}{*}{$\begin{array}{l}\text { Dummy for education high school (no formal } \\
\text { education as a reference) }\end{array}$} & $0.138^{*}$ & $0.176^{\star *}$ & $0.054^{*}$ & $-0.214^{* *}$ & $-0.153^{\star *}$ \\
\hline & $(0.072)$ & $(0.088)$ & $(0.028)$ & $(0.107)$ & $(0.077)$ \\
\hline \multirow[t]{2}{*}{ Perception of others' compliance as low } & $-0.044^{\star \star *}$ & $-0.056^{\star * \star}$ & $-0.017^{\star \star}$ & $0.068^{\star \star *}$ & $0.049^{* * *}$ \\
\hline & $(0.015)$ & $(0.019)$ & $(0.007)$ & $(0.022)$ & $(0.018)$ \\
\hline \multirow{2}{*}{$\begin{array}{l}\text { Perception of discrimination by tax admin as } \\
\text { high }\end{array}$} & -0.005 & -0.007 & -0.002 & 0.008 & 0.006 \\
\hline & $(0.011)$ & $(0.015)$ & $(0.004)$ & $(0.018)$ & $(0.013)$ \\
\hline \multirow{2}{*}{$\begin{array}{l}\text { Dummy for turnover ETB } 500,000 \text { and above } \\
\text { (turnover up to ETB } 100,000 \text { as a reference) }\end{array}$} & -0.017 & -0.022 & -0.007 & 0.027 & 0.019 \\
\hline & $(0.024)$ & $(0.031)$ & $(0.009)$ & $(0.037)$ & $(0.027)$ \\
\hline \multirow{2}{*}{$\begin{array}{l}\text { Dummy for turnover ETB } 100,000 \text { to ETB } \\
500,000 \text { (turnover up to ETB } 100,000 \text { as a } \\
\text { reference) }\end{array}$} & -0.001 & -0.001 & 0.000 & 0.001 & 0.001 \\
\hline & $(0.024)$ & $(0.031)$ & $(0.010)$ & $(0.038)$ & $(0.027)$ \\
\hline \multirow[t]{2}{*}{ Age group } & -0.002 & -0.003 & -0.001 & 0.004 & 0.003 \\
\hline & $(0.017)$ & $(0.022)$ & $(0.007)$ & $(0.027)$ & $(0.019)$ \\
\hline \multirow{2}{*}{$\begin{array}{l}\text { Dummy for professional services (others } \\
\text { including agricultural sector as a reference) }\end{array}$} & -0.024 & -0.031 & -0.010 & 0.038 & 0.027 \\
\hline & $(0.033)$ & $(0.042)$ & $(0.013)$ & $(0.051)$ & $(0.036)$ \\
\hline \multirow{2}{*}{$\begin{array}{l}\text { Dummy for trade (others including agricultural } \\
\text { sector as a reference }\end{array}$} & -0.009 & -0.012 & -0.004 & 0.014 & 0.010 \\
\hline & $(0.031)$ & $(0.039)$ & $(0.012)$ & $(0.048)$ & $(0.034)$ \\
\hline \multirow{2}{*}{$\begin{array}{l}\text { Dummy for manufacturing sector (others } \\
\text { including agricultural sector as a reference) }\end{array}$} & -0.019 & -0.025 & -0.008 & 0.030 & 0.022 \\
\hline & $(0.032)$ & $(0.041)$ & $(0.012)$ & $(0.050)$ & $(0.035)$ \\
\hline \multirow[t]{2}{*}{ Perception of government services as good } & -0.005 & -0.007 & -0.002 & 0.009 & 0.006 \\
\hline & $(0.009)$ & $(0.012)$ & $(0.004)$ & $(0.015)$ & $(0.011)$ \\
\hline \multirow[t]{2}{*}{ Perception of tax rates as high } & 0.001 & 0.002 & 0.000 & -0.002 & -0.001 \\
\hline & $(0.011)$ & $(0.015)$ & $(0.004)$ & $(0.018)$ & $(0.013)$ \\
\hline \multirow{2}{*}{$\begin{array}{l}\text { Perception of tax administration as } \\
\text { satisfactory }\end{array}$} & $0.031^{* *}$ & $0.040^{\star *}$ & $0.012^{\star *}$ & $-0.049^{* *}$ & $-0.035^{\star \star}$ \\
\hline & $(0.014)$ & $(0.018)$ & $(0.006)$ & $(0.022)$ & $(0.016)$ \\
\hline \multirow[t]{2}{*}{ Perception of corruption as high } & $-0.024^{\star \star}$ & $-0.031^{\star \star}$ & $-0.010^{\star \star}$ & $0.038^{\star *}$ & $0.027^{\star \star}$ \\
\hline & $(0.012)$ & $(0.015)$ & $(0.005)$ & $(0.019)$ & $(0.013)$ \\
\hline \multirow[t]{2}{*}{ Respondents' gender } & $-0.059^{* \star *}$ & $-0.075^{\star * *}$ & $-0.023^{\star * *}$ & $0.092^{\star \star \star}$ & $0.065^{\star \star \star}$ \\
\hline & $(0.022)$ & $(0.027)$ & $(0.009)$ & $(0.032)$ & $(0.024)$ \\
\hline
\end{tabular}

Note: Dependent variable: $=1$ if individuals think evasion occurs very frequently, $=2$ if individuals think evasion occurs frequently, = 3 if respondents think evasion occurs not so often, $=4$ if respondents think evasion occurs sometimes, $=5$ if respondents think evasion never happens. (Standard errors provided in parentheses; ${ }^{*} p<0.10,{ }^{* *} p<0.05,{ }^{* * *} p<0.01$.)

Source: survey results and own computations. 
Specifically, the robust ordered probit regression results show the existence of a statistically significant positive relation between tax compliance attitude and the perception of audit. In terms of marginal effects, an increase in the perception of probability of detection (towards the view that audit probability is high) by one point, is likely to result in a decrease in the probability of the view that evasion occurs very frequently $(2.8 \%)$, frequently $(3.6 \%)$, not so often $(1.1 \%)$, and an increase in the view that evasion occurs sometimes (4.3\%) and never (3.1\%).

Regarding the perception of others' compliance and compliance attitude, the results of ordered probit regression show a positive and statistically significant association. A one-point increase in the perception of others' compliance (thinking that others are complying) is likely to reduce the probability of the view that evasion occurs very frequently $(4.4 \%)$, frequently $(5.6 \%)$ and not so often $(1.7 \%)$. This is also likely to increase the probability of the views that evasion occurs sometimes $(6.8 \%)$ and never occurs $(4.9 \%)$.

Satisfaction with the tax administration and perception of tax compliance are found to have a statistically significant negative relation, as revealed in the ordered probit regression estimates. The marginal effects indicate that a one-point increase in the perception that the tax administration procedures and practices are not satisfactory is likely to result in an increase in the probability of the view that evasion occurs very frequently $(3.1 \%)$, frequently $(4 \%)$ and not so often (1.2\%). This is also likely to decrease the probability of the view that evasion occurs sometimes (4.9\%) and never (3.5\%).

The correlation between perception of corruption and compliance attitude is also investigated. The results of ordered probit regression show the existence of a positive and statistically significant correlation between the two. In terms of marginal effects, as Table 3 shows, a onepoint increase in the perception of corruption (towards the view that officials do not ask for unofficial payment or officials do not show corrupt behaviour) shows an increase in the likelihood that evasion occurs sometimes (3.8\%) and never (2.7\%); it also shows a decrease in the likelihood that evasion occurs very frequently $(2.4 \%)$, frequently $(3.1 \%)$ and not so often $(1 \%)$.

In addition, the ordered probit regression results find evidence of the existence of a statistically significant association between compliance attitude, gender and education. Female respondents are more likely to have a compliant attitude than male respondents. An increase in the level of education is likely to result in an increase in the views of noncompliant attitude, and a decrease in compliant attitude (Table 3).

The above discussion shows that factors including perception of satisfaction with the tax administration, others' compliance behaviour, probability of audit, perception of corruption, gender, and level of education impact on compliance attitude.

\section{Discussion and conclusions}

This paper has examined the correlation between compliance attitude and its determining factors, as identified in the theoretical frameworks presented in Section 1. Torgler and Valev (n.d.) note that the compliance literature documents a strong link between attitudes towards tax compliance and actual compliance. 
Using data obtained from a survey of business taxpayers in Addis Ababa, we have analysed the association between compliance attitude and different explanatory variables, such as the perception of government services (fiscal exchange), perception of discrimination by the tax administration (comparative treatment), political legitimacy (perception of corruption, satisfaction with the tax administration and trust), and perception of others' compliance behaviour (social influence). The results of ordered probit regression revealed a statistically significant correlation between compliance attitude and some of the factors considered in the analysis.

Economic deterrence: factors such as penalty and audit were considered. The perception of audit probability was found to have a statistically significant association with compliance attitude. This is consistent with the theoretical prediction and the findings of several previous studies from other countries. For example, Witte and Woodbury (1985) (cited in Chau and Leung 2009) find a significant positive relationship between the risk of tax audit and the rate of voluntary tax compliance. Yesegat (2009) find a significant and positive correlation between the probability of audit and the Value Added Tax (VAT) reporting compliance decision. Ali et al. (2014) also document a positive association between compliance attitude and the probability of audit.

Audit probability represents one of the tools used by tax authorities to address the problem of tax noncompliance. In fact, tax audits are considered to have both a direct deterrent effect on taxpayers actually audited, and an indirect deterrent effect on taxpayers not audited (Alm et al. 2004). Currently, the Government of Ethiopia is taking a number of measures which are expected to enhance the administration capacity of revenue authorities, including continued capacity-building programmes in various areas including audit. Measures are also being taken against tax officials who are suspected of being corrupt. These and similar measures are likely to contribute to the observed perception of taxpayers on tax audit.

Perception of others' compliance behaviour (peer influence): the perception of others' compliance was found to have a significant impact on compliance attitude. This finding is consistent with Chan et al. (2000), who find that taxpayers may still commit noncompliance so long as this noncompliance is consistent with in-group expectations and norms (cited in Chau and Leung 2009).

Perception of political legitimacy: to capture this, the study used different factors - perception of corruption, satisfaction with the tax administration, and trust in the tax administration. Of these factors, perception of corruption and satisfaction with the tax administration were found to have a statistically significant impact on compliance attitude. These findings are consistent with what the theory predicts and the findings of other empirical studies such as Ali et al (2014). As Yesegat and Fjeldstad (2013) note, taxpayers express their concern on the limited capacity of the tax administration: this signals dissatisfaction with the tax administration, which, in turn, could partially explain the poor tax compliance and, hence, poor revenue performance in Ethiopia.

Demographic factors: gender was found to have a statistically significant relation with compliance attitude - female respondents were more likely to show a compliant attitude. This is consistent with the findings of some other studies, including Torgler and Valev (n.d.). It is also a reflection of the risk-averse behaviour of women entrepreneurs in Ethiopia. Although the results are mixed, studies such as EDRI (2004) show women entrepreneurs in Ethiopia exhibit risk aversion (cited in Solomon 2010). 
Education and compliance attitude revealed a negative and statistically significant correlation a higher level of education was associated with a less compliant attitude. This result is countering findings of most other studies that have assessed the impact of tax education on tax compliance. As noted by Jackson and Milliron (1986), education relates to taxpayers' ability to comprehend and comply or not comply with the tax laws and requirements. Aspects of knowledge distinguish between the general degree of fiscal knowledge, and the degree of knowledge involving evasion opportunities (Groenland and Veldhoven 1983, cited in Chau and Leung 2009). This knowledge is considered to be important for attitudes towards tax compliance (Chau and Leung 2009). However, in this current study the knowledge considered was neither fiscal knowledge nor knowledge about evasion opportunities. Instead, the study attempted to investigate the impact of the level of general education achieved on tax compliance attitude. The results can, therefore, be interpreted as high educational achievement (general education) may have given individuals the capacity to judge the fairness and other dimensions of the tax system, the governance system at large, and to make their compliance decisions.

This study highlights a number of areas that need to be considered when addressing the problem of tax noncompliance. The findings related to satisfaction with the tax administration signal the need to investigate the tax administrative procedures and practices, and to address relevant issues. It is critical to investigate areas leading to corrupt practices and to mitigate the prevalence of actual and perceived corruption in order to increase the legitimacy of the tax system. Further, it is also important to examine whether and how tax knowledge and knowledge about evasion opportunities affect tax compliance attitude. 


\section{References}

Ali, M., Fjeldstad, O-H. and Sjursen, I. (2014) 'To pay or not to pay? Citizens' attitudes towards taxation in Kenya, Tanzania, Uganda and South Africa', World Development 64: 828-42

Allingham, M. and Sandmo, A. (1972) 'Income tax evasion: a theoretical analysis', Journal of Public Economics 1(3\&4): 323-338

Alm J., Jackson, B. and McKee, M. (2004) Audit Information Dissemination, Taxpayer Communication, and Compliance, An Experimental Approach Paper prepared for 2004 IRS Research Conference

- McClelland, G. and Schulze, D. (1999) 'Changing the social norm of tax compliance by voting', Kyklos, 52(2): 141-171

— $ـ(1992)$ 'Why do people pay taxes', Journal of Public Economics 48(1): 21-38

Andreoni, J., Erard, B. and Feinstein, J. (1998) 'Tax compliance', Journal of Economic Literature 36 (June): 818-860

Becker, G. (1968) 'Crime and punishment: an economic approach', Journal of Political Economy 76: $169-217$

Chau, G. and Leung P. (2009) 'A critical review of Fischer tax compliance model. A research synthesis', Journal of Accounting and Taxation 1(2): 034-040

Coolidge J. and Ilic, D. (2009) Tax compliance perceptions and formalization of small businesses in South Africa, Policy Research Working Paper, WPS 4992, Washington DC: World Bank

Cullis, J. and Lewis, A. (1997) 'Why people pay taxes: from a conventional economic model to a model of social convention', Journal of Economic Psychology 18: 305-321

D'Arcy, M. (2011) Why do citizens assent to pay tax? Legitimacy, taxation, and the African State, Afrobarometer Working Paper No. 126

Fjeldstad, O-H., Schultz-Herzenberg, C. and Sjursen, I. (2012) People's views of taxation in Africa: a review of research on determinants of tax compliance, ICTD Working Paper 8, Brighton: International Centre for Tax and Development

— and Semboja, J. (2001) 'Why people pay taxes: The case of the development levy in Tanzania', World Development 29: 2059-2074

Greene, W. (2002) Econometric analysis, 5th edition, Upper Saddle River, NJ: Prentice Hall, accessed at <http://stat.smmu.edu.cn/DOWNLOAD/ebook/econometric.pdf>

Hanlon, M., Mills, L. and Slemrod J. (2005) An empirical examination of corporate tax nonCompliance, Working Paper No.1025, University of Michigan 
IFC (unpublished) Tax Compliance Cost Burden and Tax Perceptions Survey in Ethiopia, IFC/WBG

Jackson and Milliron (1986) 'Tax Compliance Research: Findings, Problems, and Prospects', Journal of Accounting Literature 5: 125-165

Loo, E., McKerchar, M. and Hansford, A. (2009) 'Understanding the compliance behaviour of Malaysian individual taxpayers using a mixed method approach', Journal of the Australasian Tax Teachers Association 4(1), 181-202

__ (2008) Tax compliance behaviour: Findings derived from a mixed method design, paper presented at the 8th International Tax Administration Conference, Sydney

Marti, L., Wanjoh, M., Magutu, O. and Mokoro, J. (2010) 'Taxpayers' attitudes and tax compliance behaviour in Kenya', African Journal of Business and Management (AJBUMA) 1: 112-122

McKerchar, M. (2002) The impact of complexity upon unintentional noncompliance for Australian personal income taxpayers, PhD Thesis, Atax, University of New South Wales, Sydney

- (2001) 'Why do taxpayers comply? Past lessons and future directions in developing a model of compliance behaviour', Australian Tax Forum 16: 99-134

Nepal Ministry of Finance and GTZ (2010) A Study on Taxpayers' Satisfaction Level in Nepal, a joint project of the Inland Revenue Department (IRD) - Ministry of Finance and the GTZ, available at <www.ird.gov.np/Taxpayers_Satisfaction_Level.pdf>, accessed October 2011

Reinikka, R. and Svensson, J. (2006) 'Using micro-surveys to measure and explain corruption'. World Development 34(2): 359-370

Saad, N. (2011) 'Fairness perceptions and compliance behaviour: Taxpayers' judgments in selfassessment environments', a PhD thesis submitted to the University of Canterbury, New Zealand, available at $<\mathrm{http}: / / \mathrm{www}$.ir. .canterbury.ac.nz/bitstream/10092/5065/1/thesis_fulltext.pdf>, accessed May 2011

Sapiei, N., Kasipillai, J. and Eze, U. (2014) 'Determinants of tax compliance behavior of corporate taxpayers in Malaysia', eJournal of Tax Research 12(2): 383-409

Solomon, D. (2010) Desk Review of Studies Conducted on Women Entrepreneurs in Ethiopia, Addis Ababa Chamber of Commerce and Sectoral Associations with financial support from the Swedish Agency for International Development Cooperation, SIDA

Torgler, B. (2002) 'Speaking to theorists and searching for facts: tax morale and tax compliance in experiments', Journal of Economic Surveys 16(5): 657-683

and Schneider F. (2006) What Shapes Attitudes toward Paying Taxes? Evidence from Multicultural European Countries, discussion paper, IZA No. 2117, Institute for the Study of Labor 
and Valev, N. (n.d.) Gender and public attitudes toward corruption

and tax evasion, accessed at <http://www2.gsu.edu/ econtv/corruption_gender.pdf>

Wadhawan, S. and Gray, C. (1998) Enhancing transparency in tax administration: A survey, African Economic Policy Discussion Paper 3, available at <http://pdf.usaid.gov/pdf_docs/PNACF323.pdf>, viewed August 2011

World Bank, (n.d. a) Ethiopia Economic Overview, $<$ http://www.worldbank.org/en/country/ethiopia/overview)>

(n.d. b) Toolkit for tax administration diagnosis: Some essential questions to identify tax administration weaknesses, environmental constraints, and reform priorities, available at <siteresources.worldbank.org/INTTPA/Resources/focussedtoolkit.doc>, viewed September 2011

Yesegat, W. (2009) Value added tax in Ethiopia: A study of operating costs and compliance, PhD thesis submitted to the University of New South Wales, Australia

and Fjeldstad, O-H. (2013) Taxpayers' views of business taxation in Ethiopia: Preliminary results from in-depth interviews, a paper presented at ICTD's annual meeting held 10-12 December 2013, Lome, Togo 


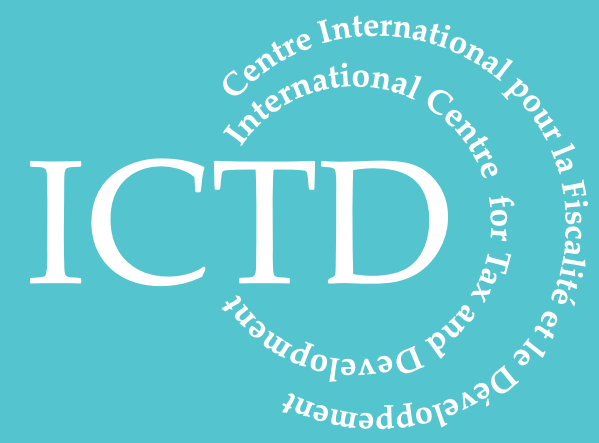

International Centre for Tax and Development at the Institute of Development Studies

Brighton BN1 9RE, UK

T: +44 (0) 1273606261

F: $+44(0) 1273621202$

E: info@ictd.ac

www.ictd.ac 